\title{
Economic structures, institutions and economic performance
}

\author{
Collin Constantine
}

*Correspondence:

k1543752@kingston.ac.uk; constantinecollin@gmail.com Department of Economics, Kingston University, London, Penrhyn Road, Kingston upon Thames, Surrey KT1 2EE, UK

\begin{abstract}
The contention that "inclusive" institutions are the deep determinants of economic growth remains unsatisfactory. This paper develops an alternative theoretical and empirical case that economic structures are the fundamental cause of economic performance. Economic structures determine the rate of structural learning, affect institutional performance, influence the distribution of income and establish the direction of political transitions, thereby, economic performance. The paper highlights the feedback loops among institutions, political power and economic structures, thus, markets on their own will not ensure growth-enhancing transformations. The workings of this framework are illustrated using a USA case study, and it exposes the structural origins of the financial crisis.
\end{abstract}

Keywords: Economic structure, Institutions, Structural transformation, Political power JEL Classification: $\mathrm{O} 14, \mathrm{O} 17, \mathrm{O} 43$

\section{Background}

Why are some countries rich and others poor? Since Solow (1956), the tentative answer has been differences in capital accumulation and technical change, but this was unsatisfactory since the theory failed to explain what accounts for these differences. Endogenous growth theories (Aghion and Howit 1992; Grossman and Helpman 1991; Romer 1990) emerged to answer the faithful call and argue that differences in research and development and human capital lead to differential growth in technical change and accumulation. Still, why do some countries invest more in education and innovation? North (1990), Acemoglu and Robinson (2013) and other new institutional economists contend that differences in institutions can explain the differences in economic performance across time and space. Institutionalists posit that economic growth is a function of economic and political institutions. This article argues that new institutionalists are guilty of the same sin committed by early growth theorists. The latter have overlooked the role of institutions in the growth process, and new institutional economists ignore the role of economic structures in the dynamics of growth.

In our view, it is not institutions that cause growth; rather, it is a country's economic structure that is the fundamental cause of economic performance. Therefore, differences in economic structures across time and space can explain the differences in economic

(c) The Author(s) 2017. This article is distributed under the terms of the Creative Commons Attribution 4.0 International License (http://creativecommons.org/licenses/by/4.0/), which permits unrestricted use, distribution, and reproduction in any medium, provided you give appropriate credit to the original author(s) and the source, provide a link to the Creative Commons license, and indicate if changes were made. 
development. This paper presents a new theoretical framework that explains how economic structures matter for growth and this is supported by a US case study.

But what are economic structures? Some commodities like high-technology manufacturing possess the scope for increasing returns, and others like bananas are notorious for demonstrating diminishing returns. A given country has an increasing returns productive structure if it produces high value added commodities that are technically sophisticated and the reverse holds - a decreasing returns economic structure is composed of low value added commodities that are technologically simple. Fundamentally, economic activities reflect an economy's productive capabilities and a country's productive structure is simply the aggregate representation of its technological capabilities.

Robust growth is realized when a country acquires an increasing returns economic structure, while economic stagnation and sporadic growth are observed otherwise. The article illustrates why increasing returns economic activities are growth enhancing. High value added and technologically complex goods are produced in market structures that are conducive for innovation (Nelson and Winter 1990; Schumpeter 2008) and these sustain higher wages and profits for longer periods (Reinert 2008). Also, increasing returns economic activities provide longer career ladders and these serve as an important means for labour to climb the ladders across social classes, which improves the distribution of income. The emerging consensus is that lower inequality is growth intensive (Stiglitz 2013, 2015b; Norris-Dabla et al. 2015; Ostry et al. 2014; Cingano 2014). Further, democratic transitions are more likely in increasing returns production structures and this enhances the diffusion of technical knowledge (Acemoglu 2008), which is an important proximate cause of growth.

How can a country acquire an increasing returns economic structure? Growthenhancing structural changes are observed when institutions of production are adequately enforced by the state (Khan 2010). Following Reinert (2007), our theoretical framework makes the distinction between institutions of production (industrial polices: tariffs, subsidies, etc.,) and institutions of exchange (property rights, rule of law, etc.,). It is obvious that without some minimal rule of law and some form of property ownership production will not be undertaken. It follows that institutions of exchange have nontrivial effects on production. However, institutions of exchange do not guarantee production or the production of goods with increasing returns. Institutions of exchange are at best necessary conditions but insufficient alone to generate production. Government subsidies and tax breaks when applied appropriately can have direct effects on production levels and incentivize the production of certain goods over others.

This distinction allows us to highlight the analytical limitations of new institutional economics, particularly the work of Acemoglu et al. (2005) and Acemoglu and Robinson (2013). These scholars make the distinction between "extractive" and "inclusive" institutions. The former refers to non-democratic political institutions on the one hand and weak rule of law and the absence of private property rights on the other. It follows that "inclusive" institutions are a web of democratic political institutions, strong rule of law and the protection of private property for a broad cross section of society. The dominant discourse on institutions contends that "inclusive" institutions are the deep determinants of long-run growth. This paper posits that both "inclusive" and "extractive" institutions focus primarily on institutions of exchange. The preoccupation with the latter is the 
outcome of the implied assumption that production capabilities already exist. But poor countries, which by definition lack production technologies, cannot ignite robust growth by "downloading" institutions of exchange from developed countries. Indeed, resources are poorly allocated in less developed countries, but imperfect exchange becomes less of a problem when one realizes that poor countries have little to exchange. We argue that institutions of exchange cannot produce growth-enhancing structural transformations. This is the principal difference between our view and the dominant discourse on institutions and development.

A key insight from our framework is that the performance of institutions is determined by a country's economic structure. Many less developed countries have some form of "inclusive" institutions-the primary problem is that these are only written in law and hardly or only selectively enforced. This article argues that this is the outcome of decreasing returns production structures. Enforcing institutions are not costless, and diminishing returns economic activities simply do not produce sufficient value added to cover the costs of enforcement. The reverse is true in rich countries with increasing returns economic structures.

Finally, our theoretical framework demonstrates how production structures affect the labour market or more concretely, the allocation of talent. A given economic structure has a given allocation of occupational rents, by this we mean the income earned by key players well above what their entrepreneurial talent justifies. The paper argues that occupational rents become an important source of de facto political power, and this in turn is used to reinforce the economic structure to preserve the distribution of occupational rents. This creates an equilibrium among political power, institutions and economic structures and explains why growth-enhancing structural change is the exception rather than the rule.

The article uses the USA as a case study to provide empirical support for our theory. The case study reveals an alternative interpretation of the recent financial crisis. While many of the prominent analyses (Eggertsson and Krugman 2012; Krugman 2009; Reinhart and Rogoff 2009) focus on poor financial regulation, liquidity traps, etc., this paper argues that the housing bubble emerged as a means to paper over the deflationary tendencies of the structural transformation away from manufacturing. One important source of the deflationary tendencies is the rise of inequality. It follows that financial crises and rising inequality are likely during unmanaged structural changes.

The remainder of the paper is organized as follows. Section 2 presents our theoretical framework, and Sect. 3 provides empirical support for our theory followed by a brief discussion. Finally, Sect. 4 concludes.

\section{A theory of economic structures}

Our basic story is that the production structure of an economy is the fundamental determinant of its economic performance. Robust growth is observed when an economy's production structure is composed of commodities with increasing returns (Andreoni and Scazzieri 2014; Dosi 1982; Hidalgo et al. 2007; Nelson and Winter 1990; Reinert 2008). Structural change is the consequence of moving into or out of these economic activities, and this is captured in aggregate by sectoral changes. For instance, the agrarian transformation into industry was essentially the withering away of economic activities 
with diminishing returns. This view of growth and structural change builds on the work of Chenery and Syrquin (1975), Kuznets (1971), Kuznets (1961), Kuznets (1957), Lewis (1954), Ocampo et al. (2009), Pasinetti (1983), Saviotti and Pyka (2004), Syrquin et al. (1984), among others. In their view, the creation of new sectors and economic activities is a necessary requirement for long-term economic development.

Hidalgo et al. (2007) explain that a country's position in the product space is a good predictor of economic performance. By product space, they mean the network representation of the relatedness or proximity between products traded in the global market. When a country produces a commodity that is located near the centre of the product space, many other related products can also be produced with given technology. But this does not hold at the periphery-goods located near the periphery are unrelated and often require vastly different technology. Therefore, Hidalgo et al. (2007) contend that growth is likely to be volatile for countries that produce commodities located at the periphery of the product space, where natural resources are abundant and commodities are produced with rudimentary technology. In contrast, growth is expected to be robust for countries that produce goods located near the centre of the product space. It follows that economic growth is the process of moving from the periphery to the centre, in other words, sustainable growth is the consequence of a certain form of structural transformation. Thus, not all structural changes are growth enhancing-a transformation from the centre to the periphery of the product space is growth reducing.

Why are economic activities with increasing returns so important? First, they are produced under varying degrees of imperfect competition and this has a number of growth-enhancing effects. Prices, wages and profits are elevated for longer periods when compared to economic activities produced in highly competitive industries. This sustains aggregate demand and serves as a robust source of internal growth. Dasgupta and Stiglitz (1980), Nelson and Winter (1990) and Schumpeter (2008) argue that imperfectly competitive market structures are more conducive for innovation and technical progress. This is supported by Andreoni (2014), who explains that the process of structural learning and technical change are determined by the type of economic structure. Thus, in the second instance, economic activities with increasing returns are also important because they serve as a proximate source of innovation. Third, they sow the seeds of economic diversification. Unlike the technical knowledge at the periphery of the produce space, the technology at the centre can be readily applied to a wide range of commodities and lead to diversification and further growth. This is an important source of economies of scale and scope and is absent in activities located at the periphery. Fourth, economic activities with increasing returns enjoy higher income and price elasticity of demand in export markets-this make them ideal growth propellers for highly open economies. Fifth, the job ladders are larger for these economic activities and this lead to a rewarding work experience. More concretely, the possibilities for the division of labour are relatively expansive and this is key to strengthen the nexus between economic growth and employment.

But the importance of commodities with increasing returns extends beyond elasticities, innovation, job ladders and diversification. There are many important positive externalities from a system of production based on economic activities with increasing returns. In particular, higher wages and profits spill over into other sectors increasing 
the overall standard of living. Bus drivers in Africa are no less efficient or productive than bus drivers in say, London. Yet, in a common currency, the wage differential is substantial. Reinert (2008) contends that the differences in production structures can explain the wage differential.

Fundamentally, a country's production structure is the basic source of its economic performance. It determines the rate of firm level innovation, diversification of economy, length of job ladders and direction of structural change.

There are many sources of structural transformation, but they can be grouped into two broad categories: (1) state intervention and (2) external shocks. State intervention encompasses the deliberate change in market incentives and the creation or destruction of markets. The experience of the emerging markets in East Asia and of old Europe during the nineteenth and twentieth centuries are examples of growth-enhancing state intervention (Chang 2003). On the other hand, external shocks include wars, natural disasters and economic shocks, etc.

Chang (2011) explains that the state is the institution of all institutions, which underscores the role of institutions in structural change and growth. But this insight differs from Acemoglu et al. (2005) and other new institutional economists. "Good" institutions, like property rights, can only ignite structural changes if they are adequately enforced, and we show that this is dependent on the type of economic structure. But even if they are enforced, there is no a priori reason why the new market incentives and economic structure should be consistent with sustainable growth. The growth implications of structural change are ambiguous.

Institutions like property rights, law and money are allocative institutions that maximize exchange in a given economic structure. Though property rights have non-trivial effects on production, Reinert (2007) notes that these are largely used to facilitate arbitrage. For instance, Reinert (2008) explains that the history of innovation is largely written by state support and accident rather than the enforcement of patent laws (property rights). Industrial polices (tariffs, subsidies, etc.,) are institutions of production that create growth promoting structural transformations. Also, this article posits that a given economic structure can be reproduced under different formal institutional settingsdemocracy or dictatorship. Therefore, if production structures are the same, economic performance can be the same in different countries with different political systems. This is unlike the thesis advanced in Acemoglu et al. (2005); in their view, political system or institution is the fundamental cause of growth. But our theory of economic structures explains that differences in economic performance lie in the different patterns and rates of structural change, not in the differences in institutions.

\subsection{Economic structures and institutions}

The debate on institutions and development is centred on the direction of causation. While new institutional economists argue that institutions cause growth, the literature on industrial policies (Chang 2003; Khan and Jomo 2000; Reinert 2008), among others, contend that growth and development determine the direction and rate of institutional change. In this article, we make two claims: (1) there is bidirectional causality between institutions and economic structures and (2) the type of economic structure determines the performance or efficacy of formal institutions. 


\subsubsection{Causality}

Institutions do not exist in abstraction; they co-evolve with an economy's production structure. The structural adjustment programs of the IMF and the second-generation reforms of the World Bank are major institutional changes that revise the rules governing business and social interactions. These reforms affect economic performance because they change the structure of economies. For instance, IMF policies have resulted in the premature collapse of many economic activities with increasing returns in Africa and Latin America and the Caribbean (LAC). While it is true that their productive capabilities were not on the global technological frontier, it is also true that the growth rates in many African and LAC countries were higher in the 1970s and 1980s as compared to the post-reform period (Chang 2011; Khan 2009; McMillan and Rodrik 2012).

But the reverse line of causation is also valid: structural transformations ignite institutional changes (Ancochea 1999; Chang 2011; Reinert 2007). The discovery of gold in California led to what is popularly known as the California gold rush. This discovery changed both the sectoral distribution of GDP and the type of economic activities produced. As is the case with institutions, the exploitation of this natural resource does not exist in abstraction; it has to be regulated under a new institutional framework. Similarly, institutional changes are needed when oil is discovered. In fact, to avoid the "Dutch Disease", strategic institutional innovation becomes necessary to ensure that the new economic structure produces sustainable growth.

It is instructive to remember Robinson Crusoe on his island. He hardly has need for the institution of limited liability or a central bank; these institutions are simply irrelevant for the production structure on the island. The key point is that one cannot understand institutions and their causal effects in isolation of production structure. But even new institutional economists understand the importance of economic structure and its relation to institutions. Their emphasis on property rights and the rule of law, etc., are means to reduce market transaction costs with the aim of maximizing gains from trade. The focus on exchange is because of an implied and too often ignored assumption that the problem of production has been solved. It is as if new institutional economists assume an increasing returns production structure. But one cannot make development policy with the assumption that the problem of production has been solved. A shrewd observer would argue that the principal problem in poor countries is the absence of production capabilities. When this problem is binding, the concern with imperfect exchange becomes immaterial.

The view that institutions are the rules that shape human interaction (North 1990) does not capture the nexus between institutions and economic structures. This definition allows for one direction of causation-from rules to consequence. But even through consequential events (state intervention and/or external shocks) institutions are formed or modified. It follows that the declaration of the primacy of institutions over all else and its one direction of causation, as in Rodrik et al. (2004), is premature to say the least.

\subsubsection{Economic structures and institutional performance}

Khan (2010) contends that institutional performance differs across time and space because of differences in political and economic structures. He explains that developed countries have a larger ratio of private sector production to GDP as compared to 
underdeveloped countries. This structural difference affects the costs and effectiveness of institutional enforcement. In developed countries with advanced production structures (composed of economic activities with increasing returns), allocative institutions are readily enforced since the proceeds from these economic activities are sufficiently high to cover the costs of enforcement. But in poor countries with little production capabilities and a plethora of commodities with diminishing returns, the gains from private contracting are hardly sufficient to cover the costs of enforcing property rights. This fundamental insight illustrates the dominance of economic structures over institutions.

At a general level, as the production of economic activities with increasing returns grow relative to diminishing returns the gains from private contracting exceed the costs of enforcing allocative institutions. Thus, in countries with advanced or increasing returns production structures, institutions of exchange perform as expected. But in the absence of these conditions, institutions of exchange are inadequately enforced. Consider the implications for poor countries. In diminishing returns production structures, the gains from private contracting are not sustainable. A great share of economic transactions is undertaken through extra-market institutions for one principal reason-the monetary gains from diminishing returns activities are not sufficient to cover the costs of enforcing formal institutions or private contracts. Extra-market institutions range from black-markets, gifts to political patronage and these can explain the prominence of corruption and poor enforcement of the rule of law observed in many less developed countries. This article contends that these extra-market institutions always over-ride "inclusive" institutions in countries with diminishing returns economic structures. To illustrate this further, consider the political dimensions.

Unlike rich countries, there is no collective or political interest in protecting and developing the private sector in poor countries. This lack of political interest explains the frequency of populist policies and continuous rule violating behaviour. The relatively small private sector necessitates a narrow tax base and a low employment premium. Inevitably, the state becomes the largest source of employment and, by extension, represents a formidable political force. In this context, "good" institutions are unlikely to be effective and the evidence indeed supports this. Countries across Africa, Asia and LAC with diminishing returns production structures are well known for being highly corrupt with weak institutions and enforcement of the rule of law (Khan 2000, 2006, 2009). North et al. (2007) argue on the contrary and explain that the form of political organization rather than economic structure determines how institutions perform. In their view, importing "inclusive" institutions on limited access orders (societies where political and economic access to key resources are limited to an elite group) do not transform society since the way elite factions are organized is at odds with these institutions.

In our view, the different forms of political organizations (limited access orders or open access orders) are the outcomes of different economic structures. In rich countries with increasing returns production structures, politics is structured around private sector interests and "good" institutions are easily enforced. "Good" institutions are consistent with private sector interest since "good will" and reputation affect the profit line of the firm. Private enterprises are unlikely to maintain market share and influence if they are tainted with corruption scandals. In contrast, politics is structured around nonprivate sector interests in poor countries (Khan 2010), where "good will" and reputation 
are of less significance to the firm. This explains why consumer protection codes, fire and other safety regulations, etc., are superficially applied in countries with diminishing returns economic structures.

This is hardly an argument to defend poor governance or corrupt business practice, but from a policy standpoint, it is imperative that we fully understand the structural reasons why institutions perform differently across geographies. Given this insight, the claim that institutions determine the rate of economic growth becomes trivial. Institutions can perform differently due to different economic structures. Any variation in economic growth can only be explained by the factor that causes variation in institutional performance-this factor is economic structure.

We have explained how institutions co-evolve with production structures, but institutions are also chosen by society (Acemoglu et al. 2005). Through the forces of globalization, institutional diversity is on a downward trend-consider the rise of democracies across the world, the adoption of independent central banks and anti-corruption bureaus, etc. Nonetheless, the argument presented here explains why expected and actual institutional performance can diverge. It is therefore important to differentiate between effective institutions and institutions as commonly understood. Institutions become effective only when they are adequately enforced. Consider the following quote from North (1994): "economies that adopt the formal rules of another economy will have very different performance characteristics than the first economy because of different informal norms and enforcement. The implication is that transferring the formal political and economic rules of successful Western economies to third-world and Eastern European economies is not a sufficient condition for good economic performance." In short, societies cannot simply download the "best" institutions and expect these to work.

\subsection{Economic structures and the allocation of talent}

The connection between economic structure and the allocation of talent has not been explored within the literature. The dominant view is that institutions determine the allocation of talent between rent seeking and entrepreneurship (Baumol 1996; Murphy et al. 1991, 1993). But we argue that a given economic structure has a given structure of occupational rents that determines the allocation of talent. For instance, FIRE $^{1}$ economies demand financial entrepreneurs, while largely agricultural economies have a labour market structure that corresponds to its economic system. An economy with "excessive" rent seeking or too many lawyers, as in Murphy et al. (1991), is principally a phenomenon of the economic structure as opposed to institutional failure.

Why occupational rents rather than occupational remuneration? The former refers to the income earned by key players of a certain economic structure well above what their entrepreneurial talent justifies. Consider the agrarian economic structure and the landlords' rent David Ricardo forcefully criticized or the financial rents earned by financiers in FIRE economies, and in the context of less developed countries, consider the political rents earned by political entrepreneurs that control access to the relatively large pool of non-market resources. In a given economic structure, there is a small group of what

${ }^{1}$ Finance, Insurance and Real Estate. 
we may call rentiers that benefit disproportionally from the production structure and the occupational rents become the regulatory mechanism for the labour market. Consequently, occupational rents serve as a source of de facto political power that one can potentially transform into de jure political power. The latter is used to enforce economic institutions that support the production structure and by extension, occupational rents. This generates an equilibrium that explains both structural and institutional rigidities. This equilibrium is unlike the stability between reward structures and the allocation of talent proposed in Acemoglu (1995). Acemoglu explains that the past allocations of talent influence future reward structures and shape the future allocation of talent-note that economic structure is missing from this equilibrium process.

Khan (2010) and Acemoglu et al. (2005) argue that institutional inertia exists because the distribution of benefits derived from the institution is consistent with the distribution of political power in society. But as explained earlier, institutions are underpinned by production structures, thus, the equilibrium is among economic structure, political power and institutions. There can be great political interest in creating structural rigidities in economic systems as long as this is beneficial to powerful groups. The financial entrepreneurs in the FIRE economy have a large cohort of lobbyists to ensure that the sector remains under-regulated and to perpetually justify an unfair tax code. In poor countries, the rural population represents a greater share of the total political constituency and this creates political incentives to maintain an unjustifiably large rural economy. While modernization is always the central objective of poor countries, the rural-urban divide is a formidable political constraint to any modernization project. Further, political entrepreneurs benefit from the rural-urban divide and enact policies to fortify this division.

The contention that economic structures determine the structure of occupational rents is a thesis about the structural origins of the distribution of income. Recent research has established a robust empirical relationship between production structure and the distribution of income (Hartmann et al. 2015). Economic structures determine the pre-tax income across various occupations. In the absence of redistributive transfers, the distribution of income across sectors and occupations affect economic performance, to the extent that these reinforce the economic structure. Piketty (2014) and Stiglitz (2013) explain that the rise of inequality in rich countries is due to the increasing gap of the income share between the $1 \%$ and the $99 \%$. Based on the framework presented here, the income share of the top $1 \%$ is largely an outcome of the economic structure, specifically, the rise of the FIRE economy (see Onaran and Stockhammer 2011; Stiglitz 2013, 2015a). The latter has become the principal regulator of growth in the USA and other developed countries (Lapavitsas and Powell 2013). This structural change has manifested itself in a labour market geared towards finance, which reinforces the FIRE economy. Over time, this equilibrium engenders Minsky cycles (Minsky 1992) and lead to financial crises.

Distributional conflicts are essentially a struggle over property rights to the gains from growth. This means that the rise of inequality is not only structurally determined but also represents an increasing concentration of property rights. This is the epitome of "extractive" institutions in the sense that Acemoglu et al. (2005) use this term. If a broad cross section of society has property rights, then the gains from growth must be shared among a broad cross section of society. Yet, growth in the USA and other developed 
countries over the past four decades have not been inclusive (Piketty 2014), even though these countries are known for having "inclusive" institutions and stable property rights. This means either the theory proposed by Acemoglu et al. (2005) or the empirical assessment of institutions in developed countries is flawed or both. In our view, there are limitations on both fronts.

\subsection{Economic structures and political transitions}

The central aim of Political Economy is to emphasize the importance of politics for economic outcomes. Acemoglu et al. (2014) have provided empirical support for the claim that liberal democracy does cause growth, but this finding was recently overturned by Pozuelo et al. (2016). It is important to differentiate between liberal and electoral or illiberal democracies (Zakaria 2013). Besides regular elections, electoral democracies violate civil liberties, censor the media and fundamentally establish an authoritarian form.

Can economic structures predict political transitions? Acemoglu and Robinson (2006) in their book, Economic Origins of Dictatorship and Democracy, have proposed a theory of democratic transition and consolidation that is based on a country's economic structure. The latter is defined as either land or capital intensive and though this view is different from ours, the difference can be easily reconciled. Among the economic activities located at the periphery of the product space are natural resources like oil, gold and land. Also, it is not incorrect to say that the goods/services located at the centre of the product space are capital intensive.

Whether a country transitions to or consolidates democracy depends on whether the source of income of the elites is easily taxed (Acemoglu and Robinson 2006). When a country's economic structure is land intensive, a democratic transition imposes significant redistributive costs to the landlord elites since the newly empowered masses can easily impose high land taxes. Elites in these economic structures choose repression instead of democracy to forgo the redistributive burden. In contrast, industrial elites facilitate a democratic transition since it is harder to tax capital income and entrepreneurship in capital intensive economic structures. In short, economic development towards a capital intensive economic structure promotes democracy (Acemoglu and Robinson 2006).

It is instructive to recall Acemoglu et al. (2005)'s theory of economic growth. Inclusive political institutions (democracy) and inclusive economic institutions (property rights, etc.) are the fundamental causes of economic growth. Yet, in Acemoglu and Robinson (2006) they posit that it is a country's economic structure that determines whether a country transitions to or consolidates democracy. Given this examination, it is economic structure that is the fundamental cause of long-run growth.

But our framework provides a richer analysis of the link between economic structure and democracy. An increasing returns economic structure produces commodities with longer career ladders and creates a mechanism to climb the ladders across social classes. This provides the means to larger lifetime earnings for an individual, which can improve the distribution of income. A fairer distribution of income is the anti-thesis to "extractive" institutions, and this makes it easier for "inclusive" political institutions to be enforced. 
As explained earlier, in increasing returns production structures both wages and profits are sustained for longer periods. This is a recipe for the creation or maintenance of a strong middle class, an important ingredient to the creation and maintenance of democracies (Acemoglu and Robinson 2006). Note that structural transformation to an increasing returns economic structure does not inevitably lead to democratic transitions or consolidation; it simply makes the enforcement of "inclusive" institutions feasible. It is important to underline the difference between our theory of political transitions and the modernization hypothesis (Lipset 1959), which claims that growth in per capita income causes the creation and consolidation of democracies. There are many non-democratic countries with high per capita incomes but with diminishing returns economic structures-Equatorial Guinea is a case in point. Per capita income is not economic structure. Further, after controlling for country fixed effects, the relationship between per capita income and democracy breaks down (Acemoglu et al. 2008).

Khan (2010) argues that democratic transitions become more likely when private sector production to GDP expands. Khan explains that entrepreneurs pay more taxes and thus have more at stake in the political system and consequently demand a greater say. This line of thought is consistent with our work: as an economy transitions to an increasing returns production structure, democratic transitions are more likely. This is unlike North et al. (2007) and their necessary conditions for democratic transitions. They posit that: (1) a rule of law for elites, (2) civil society organizations and (3) a centralized and consolidated control of violence are necessary, though not sufficient prerequisites for democratic transitions. But we have already demonstrated that the performance of conditions (1) and (2) depend on economic structures, making these less than robust conditions for democratic transitions. Also, condition (3) is a necessary factor for stability in democratic and non-democratic states, which makes this a less than interesting necessary condition for democratic transitions.

The critical junctures hypothesis (Acemoglu and Robinson 2013; Moore 1966; Eggertsson and Sokoloff 1997 among others) explains that historical events like colonialism are a better explanation for divergent paths. Under diverse colonial strategies, different institutions were established, "inclusive" and "extractive", and this explains the divergence in political institutions and economic performance. We agree that critical junctures are important. Some colonial strategies deliberately prevented colonies from producing commodities with increasing returns and by extension, prevented growth-enhancing structural change. Colonialism was not anti-development because of "extractive" institutions; it was anti-development because colonialists restricted production to only a handful of commodities with limited scope for structural learning.

In their book, Why Nations Fail, Acemoglu and Robinson (2013) made the observation that poor innovation and "extractive" institutions are correlated while innovations coexist with "inclusive" institutions. In Acemoglu (2008), the author highlights the political origins of technological change-in less democratic societies, political elites create entry barriers into different economic activities (oligarchic property rights), but in democratic societies, there is free entry and exit (democratic property rights). Over time, as comparative advantage changes in favour of the excluded groups, oligarchic property rights reduce efficiency and slow down technical progress. In contrast, democratic or "inclusive" political institutions promote innovation and long-run growth. 
While democratic property rights may diffuse the technical knowledge across society, these democratic property rights are irrelevant in diminishing returns production structures with a low technological base. This is the key difference between our view and Acemoglu (2008). Just as private property rights in the absence of productive capabilities are insufficient to increase production, democratic institutions without a technological base can hardly diffuse or promote technological progress. The observation in Acemoglu and Robinson (2013) is simply reflective of differences in economic structures, and this explains the different political institutions and rate of technical progress. Building on Acemoglu (2008), we now have two routes through which economic structures determine the rate of technical change and economic growth: the economic route, which we have already explained, and now the political route-from economic structures to political transitions to technical change.

\subsection{A simple model}

Pulling all the pieces together result in the following basic representation of our theory (see Fig. 1). Economic structure determines the distribution of income, and this serves as the basis for de facto and de jure political powers. The acquired political power is used to perpetuate the distribution of income through the enforcement of institutions that reinforce the production structure. Finally, the economic structure determines the rate of economic growth. This is the basic process by which institutions, political power and economic structures reproduce each other.

During structural transformations, the distribution of income and de jure and de facto political powers change and this facilitates the enforcement of new institutions to regulate the new economic structure. Specifically, growth-enhancing structural changes are observed when institutions of production are effectively enforced by the state. This can potentially ignite democratic transitions or consolidation and increase the transmission of technology across the economy. In contrast, economic stagnation and growth accelerations and collapses are observed in many parts of the world and these economies are usually embedded in electoral democracies. The origin of their failure to strengthen their democracies and provide a sustainable base for economic growth lies in their diminishing returns economic structure.

\section{Evidence}

We review the relevant changes in the US economy since the agrarian transformation to provide empirical support for our theory. The US economy is chosen because of the recent financial crisis. Similar to Gatti et al. (2012), we highlight the structural causes of the financial crisis, but our work differs from theirs in important ways. Gatti et al.

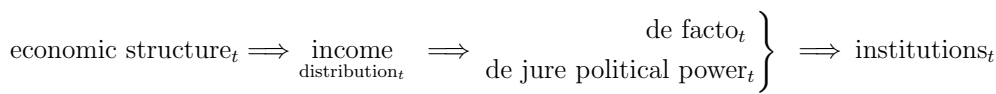

$$
\begin{aligned}
& \text { institutions }_{t+1} \Longrightarrow \text { economic structure }_{t+1} \Longrightarrow \text { economic performance }_{t+1}
\end{aligned}
$$

Fig. 1 Schematic of economic structures, institutions and economic performance 
(2012) explain that due to labour market rigidities the structural change from agriculture to manufacturing was stalled and this caused the great depression. They argue that the present crisis is the outcome of a stalled transformation from manufacturing to services.

We agree with the central theme of this analysis but with the aid of our theory, we are able to provide insights into the roles inequality and institutions played in the great depression and recession. In addition to this US case study, the literature on industrial and technology policy provide empirical support for our theory (Chang 2003; Hausmann and Rodrik 2003; Khan 2013; Mazzucato 2013; Reinert 2008; Stiglitz et al. 2014; Wade 2004, among many others) - that economic structures are the fundamental cause of long-run growth.

\subsection{US case study}

During the 1800s, the agrarian economy contributed the most to US GDP and much of the world's output. But farm productivity shocks and expanded cultivation substantially reduced agricultural prices and incomes in the early 1900s (League of Nations 1931; Timoshenko 1933), and this affected the structure of the economy in important ways. The decline was especially severe between 1929 and 1932-agricultural incomes decreased by $50 \%$. One important implication of this secular decline is the shedding of agricultural employment that led to massive joblessness, since new sectors and economic activities failed to fully utilize the growing pool of the unemployed. In theory, the purchasing power of urban wages increased, but this expansionary effect was stifled by the drastic contraction of agricultural demand for urban commodities (Gatti et al. 2012). This depressed demand in both the rural and urban economies paved the way for a secular stagnation.

This period of structural change inevitably altered the distribution of occupational rents against rural labour, which increased rural-urban inequality and exacerbated the deflationary tendencies of the transformation. To fully grasp the distributional implications, it is useful to remember that during this period initial levels of inequality were already high. Piketty (2014) notes that from 1800-1910, private capital as a percentage of national income was on average $700 \%$ for Germany, France and Britain, while in the USA, it ranged from 300 to $500 \%$. In agrarian economies, the ownership of capital was highly concentrated leading to significant inequalities of wealth and income. Though some landowners had lost private wealth during the agrarian transformation, the loss of agricultural employment countered any tendency to reduce wealth inequality.

During this transformation, manufacturing, construction and trade services were the newly emerging sectors, which demonstrated a structural change towards the centre of the product space or to an increasing returns production structure. But Gatti et al. (2012) explain that the transformation was not complete and could not have been completed under market institutions alone. In other words, labour market forces alone were insufficient to facilitate the necessary rural-urban migration. There were specific labour market rigidities that prevented rural labour from migrating to the cities and sufficient technological bottlenecks that stymied manufacturing growth (Gatti et al. 2012). Therefore, the structural transformation was not growth enhancing, especially in consideration of the deflationary tendencies. World War I (WWI) served as a temporary boost to economic growth in the US economy and accelerated the transformation to an 
increasing returns economic structure but the process remained incomplete. Based on our theory, we expect institutional reforms to follow that serve only the interests of economic elites.

Increase in rural-urban inequality and mass agricultural unemployment alter de facto political power, which influenced de jure political power to reduce top income tax rates, among other things, and this worsened inequality. High inequality and forced savings during WWI created a large pool of loanable funds that did not find profitable avenues in agriculture, and the newly emerging industrial sector was insufficient to exploit the excess savings. These gave way to the unfortunate idea of cheap credit or buy now and pay later. Consequently, this created a debt-induced growth model since consumption expenditures exceeded the declining agricultural and urban incomes.

It is difficult to sustain economic growth based on high inequality and an incomplete structural transformation. As opposed to a structural change to an increasing returns production structure with longer career ladders and lower inequality, the economic elites chose to fuel a consumption boom based on cheap credit, which facilitated financial speculation and the growth in household debt. Collectively, these created a stock market bubble that led to the great depression. There were two responses to the latter: (1) Keynesian pump priming and (2) forced industrial policies that embodied the war effort in World War II (WWII). The latter was a non-market intervention aimed at industrializing the USA to manufacture airplanes, weaponry and armours. Unlike the earlier period of structural change, the newly industrialized USA forced labour off the farms and absorbed idle labour into factories. This process essentially put an end to the great depression and forged a new equilibrium. The growth effects of this structural transformation are well documented and are best summed up in the phrase-"the golden age of capitalism".

This period (1950-1975) marked the completion of the transformation to an increasing returns economic structure, where industry accounted for a growing share of output and employment (Rowthorn and Wells 1987; Singh 1977). Glyn et al. (1988) explain that this was a period of massive growth in capital stock and labour productivity and parallel growth in real wages and productivity. While the great depression and WWII were important shocks that reduced inequality (Piketty 2014), the growth of manufacturing jobs and career ladders, strong unions and a tighter relationship between wages and productivity also stabilized the growth of inequality. This was a period of stable property rights that created a sufficient wedge between de facto and de jure political powers. Proof of this is the fact that tax rates on top incomes increased to 90\% (Piketty 2014), an important contrast to the periods before the depression.

It is not a coincidence that this period accompanied extensive industrial policies to promote growth-enhancing structural change. The USA was the only country with a trade surplus after WWII and was in a unique position to create what Varoufakis (2013) calls a global reserve recycling mechanism (GRM). The Marshal Plan, to rebuild war torn Europe, was the creation of this mechanism. It also served the purpose of containing the Soviet Union through the re-industrialization of Germany, Britain and France. After the Korean crisis, a second Marshal Plan became essential and the USA through its (GRM), aided Japan in its industrialization process. The principal point is that there 
was a convergence towards an increasing returns economic structure among the leading countries in the world economy and this created a global engine of sustainable growth.

After the completion of both Marshal Plans the USA lost significant global market share (Varoufakis 2013). This ushered in yet again, a new phase of structural transformation. The success of the global reserve recycling mechanism, similar to the success of technical progress in the farm economy, led to de-industrialization and the subsequent loss of manufacturing employment. Occupational rents changed against industrial labour and deflationary tendencies emerged. Further, career ladders became shorter in both industry and the service sector. As manufacturing employment declined, wage shares trended downwards and the overall functional income distribution worsened. As the income share of the middle class declined, the de facto political power of economic elites, who are increasingly financiers, increased.

These changes in the distribution of income and political power led to new institutions like tax cuts, financial de-regulation, de-unionization, etc., in the early 1980s. This paved the way for a new economic structure that is now reproduced by the FIRE economy. Unlike the earlier periods of structural change, there was no world war to compensate for the deflationary effects associated with rising inequality, so the old strategy of credit booms was used to boost growth. This was sustained by cheap credit, debt accumulation and a housing bubble that eventually collapsed, as the strategy did in the great depression.

The rise of the FIRE economy worsened inequality (Stockhammer 2013) and stalled the new process of structural transformation. Growth was not based on economic activities with increasing returns; rather, a financial bubble stimulated the economy. Given this analysis, the recent global financial crisis is the consequence of a stalled structural transformation, where the top $1 \%$ income earners, through their de facto influence, hold the levers of de jure political power to reinforce the system. What is missing today is a modern Marshal Plan or new institutions of production to accelerate the pace of the transformation so that advanced technologies in the USA can be applied to new increasing returns economic activities.

\subsection{A brief discussion}

This case study supports the view that the direction and rate of structural change are the ultimate determinants of economic performance. One key mechanism by which structural transformations affect growth is through the changes in the distribution of income and its corresponding influence on political institutions. This insight leads to an important conclusion that the distribution of property rights is endogenous. Even if broadbased property rights are well defined and enforced, there can be external shocks that ignite structural changes and disturb this equilibrium. This undermines Acemoglu and Robinson (2013)'s contention that "good" institutions have feedback loops that prevent the efforts of elites to undermine them. More fundamentally, Acemoglu et al. (2005)'s distinction of "inclusive" and "extractive" institutions may be an over simplification. The case study demonstrates periods of extractive growth, meaning the co-existence of rising inequality and economic growth. But this is contrary to the predictive outcomes associated with "inclusive" institutions, and Acemoglu et al. (2005) do consider the USA to be a robust example of a society with strong and "inclusive" institutions. 
The evidence in this case study supports our view that economic structures and institutions reinforce each other. As the economic structure changed, so did occupational rents and political power. This in turn created and enforced new institutions that were consistent with the new distribution of occupational rents and economic structure. It is this equilibrium dynamic that creates structural rigidities. An additional insight is that high inequality is the likely outcome of structural changes away from increasing returns production structures. This has the consequence of creating deflationary outcomes that may be papered over by credit booms and a debt-induced growth model, which increases the likelihood of financial crises.

It is also useful to note that WWII and the (GRM) not only accelerated structural transformation but were specific institutions of production that nudged structural change in the direction of increasing returns economic activities. Though the recent decline in manufacturing was not a change in knowledge base per se, it was an important loss of production capabilities that provided ladders across social classes and a wide scope for structural learning. Unless new economic activities are produced with similar characteristics the social and economic consequences for the US economy are nothing short of dismal.

\section{Conclusion}

This paper argues that economic structures are the fundamental cause of long-run growth or stagnation. Different economic structures have different scopes for structural learning, innovation and various effects on the distribution of income, which are key determinants of economic performance. Further, our theory explains why some countries are more likely to transition into liberal democracies and the implication this has for technical change, an important proximate cause of economic growth. Economic structures matter.

Our theory of economic structures explains why institutions perform differently across time and space, which highlights the folly in the World Bank's Good Governance reforms, no matter how well intended. For instance, the Bank's Governance reform framework assumes that simply downloading "inclusive" or Anglo-American institutions will improve the social economies in less developed countries. But this article demonstrates that how these institutions perform depend on economic structures.

The paper shows using a US case study that the source of the recent financial crisis rests in the structural features of the economy. The ongoing de-industrialization increases inequality, and a debt-intensive credit boom emerged to compensate for the deflationary effects of this structural change.

While the literature on industrial and technology policy are occupied with documenting cases of success and failure, the theory of economic structures and structural change remain underdeveloped. The forceful implementation of austerity in Europe and other parts of the world, even after evidence points to less austere policies, illustrates the power theory has over public policy. This paper must be understood as a call to enhance our theoretical understanding of structural change. We argue that economic structures must be placed at the centre of the analysis to better understand economic change, disparities in income and differences in political economy dynamics across time and space. Future work needs to integrate theories of financial crises with the theory of structural 
change, and in-depth research is needed for a complete understanding of how economic structures affect the distribution of income. Finally, we need to return to the days of high development theory with economic structures in the driving seat.

\section{Acknowledgements}

I thank two anonymous referees, Duane Edwards and participants at the New Developmentalism Conference in Sao Paulo, Brazil, 25th-26th, July 2016 for valuable comments on an earlier draft.

\section{Competing interests}

The author declares that he has no competing interests.

Received: 23 August 2016 Accepted: 26 January 2017

Published online: 10 February 2017

\section{References}

Acemoglu D (1995) Reward structures and the allocation of talent. Eur Econ Rev 39(1):17-33

Acemoglu D (2008) Oligarchic vs. democratic societies. J Eur Econ Assoc 6(1):1-44

Acemoglu D, Robinson J (2006) Economic origins of dictatorship and democracy. Cambridge University Press, New York Acemoglu D, Robinson J (2013) Why nations fail: the origins of power, prosperity and poverty. Profile Books, London

Acemoglu D, Johnson S, Robinson J (2005) Institutions as the fundamental cause of long run growth. In: Aghion P, Durlauf S (eds) Handbook of economic growth. Harvard University Press, Cambridge

Acemoglu D, Johnson S, Robinson J, Yared P (2008) Income and democracy. Am Econ Rev 98(3):808-842

Acemoglu D, Naidu S, Restrepo P, Robinson J (2014). Democracy does cause growth. NBER working papers 20004. National Bureau of Economic Research Inc

Aghion P, Howit WP (1992) A model of growth through creative destruction. Econometrica 60(2):323-351

Ancochea DS (1999) The role of the state in structural change: an institutionalist approach. Transregional Center for Democratic Studies working paper. New School University, New York

Andreoni A (2014) Structural learning: embedding discoveries and the dynamics of production. Struct Change Econ Dyn 29(2):58-75

Andreoni A, Scazzieri R (2014) Triggers of change: structural trajectories and production dynamics. Camb J Econ 38(6):1391-1408

Baumol JW (1996) Entrepreneurship: productive, unproductive and destructive. J Bus Ventur 11(1):3-22

Chang JH (2003) Kicking away the ladder: development strategy in historical perspective. Anthem Press, London

Chang JH (2011) Institutions and economic development. J Inst Econ 7(4):473-498

Chenery HB, Syrquin M (1975) Patterns of development: 1950-1970. Oxford University Press, Oxford

Cingano F (2014) Trends in income inequality and its impact on economic growth. OECD social, employment and migration working paper series, no. 163. OECD Publishing

Dasgupta P, Stiglitz J (1980) Industrial structure and the nature of innovative activity. Econ J 90(358):266-293

Dosi G (1982) Technological paradigms and technological trajectories: a suggested interpretation of the determinants and directions of technical change. Res Policy 11(3):147-162

Eggertsson BG, Sokoloff LK (1997) Factor endowments, institutions and differential paths of growth among new world economies. In: Haber SH (ed) How Latin America fell behind. Stanford University Press, Stanford

Eggertsson BG, Krugman P (2012) Debt, deleveraging and the liquidity trap: a Fisher-Minsky-Koo approach. Q J Econ 127(3):1469-1513

Gatti DD, Gallegati M, Greenwald B, Russo A, Stiglitz J (2012) Sectoral imbalances and long run crises. In: Allen Franklin, Masahiko Aoki NKRGJS, Fitoussi J-P (eds) The global macro economy and finance. Palgrave Macmillan, Basingstoke

Glyn A, Hughes A, Lipietz A, Singh A (1988) The rise and fall of the golden age. Wider working papers, WP 43. World Institute for Development Economics Research of the United Nations University

Grossman H, Helpman E (1991) Innovation and growth in the global economy. MIT Press, Cambridge

Hartmann D, Guevara MR, Jara-Figueroa C, Aristaran M, Hidalgo C (2015) Linking economic complexity, institutions and income inequality. Working paper

Hausmann R, Rodrik D (2003) Economic development as self discovery. J Dev Econ 72(2):603-633

Hidalgo C, Klinger B, Barabasi A, Hausmann R (2007) The product space conditions the development of nations. Science 317(5837):482-487

Khan M (2000) Rent-seeking as process. In: Khan M, Sundaram KJ (eds) Rents, rent-seeking and economic development. Cambridge University Press, Cambridge, pp 70-144

Khan M (2006) Determinants of corruption in developing countries: the limits of conventional economic analysis. In: Rose-Ackerman S (ed) International handbook on the economics of corruption. Edward Elgar, Cheltenham, pp $216-244$

Khan M (2009) The political economy of industrial policy in Asia and Latin America. In: Dosi G, Cimoli M (eds) Industrial policy and development. Oxford University Press, Oxford

Khan M (2010) Political settlements and the governance of growth enhancing institutions. Unpublished

Khan M (2013) Political settlements and the design of technology policy. In: Tiglitz J, Lin J, Patel E (eds) The industrial policy revolution II. Africa in the 21st century. Palgrave Macmillan, London

Khan M, Jomo SK (eds) (2000) Rents, rent-seeking and economic development. Cambridge University Press, Cambridge Krugman P (2009) The return of depression economics and the crisis of 2008. W.W. Norton \& Company, New York 
Kuznets S (1957) Quantitative aspects of the economic growth of nations: Il. Industrial distribution of national product and labour force. Econ Dev Cult Change 5(4):3-111

Kuznets S (1961) Quantitative aspects of the economic growth of nations: VI. Long term trends in capital formation proportions. Econ Dev Cult Change 9(4):3-124

Kuznets S (1971) Economic growth of nations: total output and production structure. Harvard University Press, Cambridge

Lapavitsas C, Powell J (2013) Financialisation varied: a comparative analysis of advanced economies. Camb J Reg Econ Soc 6(3):359-379

League of Nations (1931) The agricultural crisis. League of Nations, Geneva

Lewis AW (1954) Economic development with unlimited supplies of labour. Manch Sch 22(2):139-191

Lipset MS (1959) Some social requisites for democracy: economic development and political legitimacy. Am Polit Sci Rev 53(1):69-105

Mazzucato M (2013) The entrepreneurial state: debunking public vs. private sector myths. Anthem Press, London

McMillan M, Rodrik D (2012) Globalization, structural change and productivity growth. In: Bacchetta M, Jansen M (eds) Making globalization socially sustainable. International Labour Office with the World Trade Organization

Minsky H (1992) The financial instability hypothesis. Levy Institute Economics working paper archive 74

Moore B (1966) Social origins of dictatorships and democracy. Beacon Press, Boston

Murphy KM, Shleifer A, Vishny W (1991) The allocation of talent: implications for growth. Q J Econ 106(2):503-530

Murphy KM, Shleifer A, Vishny W (1993) Why is rent seeking so costly to growth? Am Econ Rev 83(2):409-414

Nelson R, Winter S (1990) An evolutionary theory of economic change. Harvard University Press, Cambridge

Norris-Dabla E, Kochhar K, Ricka F, Suphaphiphat N, Tsounta E (2015) Causes and consequences of income inequality: a global perspective. International Monetary Fund (IMF), Strategy, Policy and Review Department. IMF Staff Discussion Note, SDN/15/13

North D (1990) Institutions, institutional change and economic performance. Cambridge University Press, Cambridge

North D (1994) Economic performance through time. Am Econ Rev 84(3):359-368

North D, Wallis JJ, Web S, Weingast B (2007) Limited access orders in the developing world: a new approach to the problems of development. World Bank policy research working paper, WPS5359

Ocampo AJ, Rada C, Taylor L (2009) Growth and policy in developing countries: a structuralist approach. Columbia University Press, New York

Onaran O, Stockhammer E (2011) Financialization, income distribution and aggregate demand in the USA. Camb J Econ 35(4):637-771

Ostry J, Berg A, Tsangarides C (2014) Redistribution, inequality and growth. International Monetary Fund (IMF), Research Department. IMF Staff Discussion Note, SDN/14/02

Pasinetti L (1983) Structural change and economic growth: a theoretical essay on the dynamics of the wealth of nations. Cambridge University Press, Cambridge

Piketty T (2014) Capital in the 21st century. Harvard University Press, Cambridge

Pozuelo J, Slipowitz A, Vuletin G (2016) Democracy does not cause growth. Inter-American Development Bank (IDB) working paper series, no. IDB-WP-694

Reinert E (2007) Institutionalism, ancient, old and new: a historical perspective on institutions and uneven development. In: Chang HJ (ed) Institutional change and economic development. United Nations University Press, Tokyo

Reinert $\mathrm{E}$ (2008) How rich countries got rich and why poor countries stay poor. Public Affairs

Reinhart C, Rogoff K (2009) This time is different: eight centuries of financial folly. Princeton University Press, Princeton

Rodrik D, Subramanian A, Trebbi F (2004) Institutions rule: the primacy of institutions over geography and integration in economic development. J Econ Growth 9(2):131-165

Romer P (1990) Endogenous technical change. J Polit Econ 98(5):71-102

Rowthorn R, Wells J (1987) Deindustrialization and foreign trade. Cambridge University Press, Cambridge

Saviotti P, Pyka A (2004) Economic development, qualitative change and employment creation. Struct Change Econ Dyn 15(3):265-287

Schumpeter J (2008) Capitalism, socialism and democracy. Harper Perennial Modern Classics, New York

Singh A (1977) The U.K. industry and the world economy: a case of deindustrialization? Camb J Econ 1(2):113-136

Solow R (1956) A contribution to the theory of economic growth. Q J Econ 70(1):65-94

Stiglitz J (2013) The price of inequality. W.W Norton and Company, New York

Stiglitz I (2015a) New theoretical perspectives on the distribution of income and wealth among individuals: part IV: land and credit. NBER working papers 21192. National Bureau of Economic Research Inc

Stiglitz J (2015b) Rewriting the rules of the American economy: an agenda for growth and shared prosperity. W.W Norton and Company, New York

Stiglitz J, Greenwald B, Aghion P, Arrow K, Solow R (eds) (2014) Creating a learning society: a new approach to growth, development and social progress. Columbia University Press, New York

Stockhammer E (2013) Why have wage shares fallen? A panel analysis of the determinants of functional income distribution. The International Labour Organization Project, new perspectives on wages and economy, ILO working paper 470913

Syrquin M, Taylor L, Westphal L (eds) (1984) Economic structure and performance: essays in Honour of Hollis B. Chenery. Academic Press, Orlando

Timoshenko PV (1933) World agriculture and the depression. University of Michigan, School of Business Administration, Bureau of Business Research, Ann Arbor

Varoufakis Y (2013) The global minotaur: America, Europe and the future of the global economy. Zed Books, London

Wade R (2004) Governing the market: economic theory and the role of the government in east Asian industrialization. Princeton University Press, Princeton

Zakaria F (2013) The rise of illiberal democracy. Foreign Aff 76(6):22-43 